\title{
Novel fused tetrathiocines as antivirals that target the nucleocapsid zinc finger containing protein of the feline immunodeficiency virus (FIV) as a model of HIV infection
}

Asquith, Christopher R M ; Meli, Marina L ; Konstantinova, Lidia S ; Laitinen, Tuomo ; Poso, Antti ; Rakitin, Oleg A ; Hofmann-Lehmann, Regina ; Allenspach, Karin ; Hilton, Stephen T

\begin{abstract}
A novel series of fused tetrathiocines were prepared for evaluation of activity against the nucleocapsid protein of the feline immunodeficiency virus (FIV) in an in vitro cell culture approach. The results demonstrated that the compounds display potent nanomolar activity and low toxicity against this key model of HIV infection.
\end{abstract}

DOI: https://doi.org/10.1016/j.bmcl.2014.12.047

Posted at the Zurich Open Repository and Archive, University of Zurich

ZORA URL: https://doi.org/10.5167/uzh-106691

Journal Article

Accepted Version

Originally published at:

Asquith, Christopher R M; Meli, Marina L; Konstantinova, Lidia S; Laitinen, Tuomo; Poso, Antti; Rakitin, Oleg A; Hofmann-Lehmann, Regina; Allenspach, Karin; Hilton, Stephen T (2015). Novel fused tetrathiocines as antivirals that target the nucleocapsid zinc finger containing protein of the feline immunodeficiency virus (FIV) as a model of HIV infection. Bioorganic Medicinal Chemistry Letters, $25(6): 1352-1355$.

DOI: https://doi.org/10.1016/j.bmcl.2014.12.047 


\section{Accepted Manuscript}

Novel fused tetrathiocines as antivirals that target the nucleocapsid zinc finger containing protein of the feline immunodeficiency virus (FIV) as a model of HIV infection

Christopher R.M. Asquith, Marina L. Meli, Lidia S. Konstantinova, Tuomo Laitinen, Antti Poso, Oleg A. Rakitin, Regina Hofmann-Lehmann, Karin Allenspach, Stephen T. Hilton

PII: S0960-894X(14)01355-9

DOI: http://dx.doi.org/10.1016/j.bmcl.2014.12.047

Reference: $\quad$ BMCL 22292

To appear in: $\quad$ Bioorganic \& Medicinal Chemistry Letters

Received Date: $\quad 31$ July 2014

Revised Date: $\quad 12$ December 2014

Accepted Date: $\quad 13$ December 2014

Please cite this article as: Asquith, C.R.M., Meli, M.L., Konstantinova, L.S., Laitinen, T., Poso, A., Rakitin, O.A., Hofmann-Lehmann, R., Allenspach, K., Hilton, S.T., Novel fused tetrathiocines as antivirals that target the nucleocapsid zinc finger containing protein of the feline immunodeficiency virus (FIV) as a model of HIV infection, Bioorganic \& Medicinal Chemistry Letters (2014), doi: http://dx.doi.org/10.1016/j.bmcl.2014.12.047

This is a PDF file of an unedited manuscript that has been accepted for publication. As a service to our customers we are providing this early version of the manuscript. The manuscript will undergo copyediting, typesetting, and review of the resulting proof before it is published in its final form. Please note that during the production process errors may be discovered which could affect the content, and all legal disclaimers that apply to the journal pertain. 


\section{Graphical Abstract}

To create your abstract, type over the instructions in the template box below.

Fonts or abstract dimensions should not be changed or altered.

Novel fused tetrathiocines as antivirals that
target the nucleocapsid zinc finger
containing protein of the Feline
Immunodeficiency Virus (FIV) as a model of
HIV infection

\section{Leave this area blank for abstract info.}

Christopher R. M. Asquith, Marina L. Meli, Lidia S. Konstantinova, Tuomo Laitinen, Antti Poso, Oleg A. Rakitin, Regina Hofmann-Lehmann, Karin Allenspach, Stephen T. Hilton*
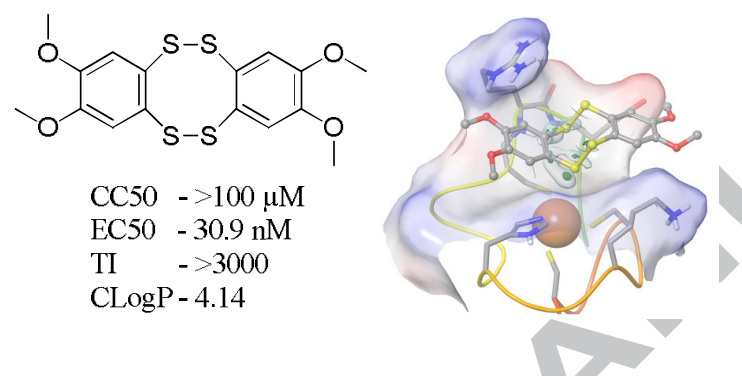


\section{Novel fused tetrathiocines as antivirals that target the nucleocapsid zinc finger containing protein of the Feline Immunodeficiency Virus (FIV) as a model of HIV infection}

Christopher R. M. Asquith ${ }^{\mathrm{a}}$, Marina L. Meli ${ }^{\mathrm{b}}$, Lidia S. Konstantinova ${ }^{\mathrm{c}}$, Tuomo Laitinen ${ }^{\mathrm{d}}$, Antti Poso $^{\mathrm{d}}$, Oleg A. Rakitin ${ }^{\mathrm{c}}$, Regina Hofmann-Lehmann ${ }^{\mathrm{b}}$, Karin Allenspach ${ }^{\mathrm{e}}$, Stephen T. Hilton ${ }^{\mathrm{a}}{ }^{*}$

${ }^{a}$ UCL School of Pharmacy, Faculty of Life Sciences, University College London, London, WC1N 1AX, United Kingdom

${ }^{b}$ Clinical Laboratory and Center for Clinical Studies, Vetsuisse Faculty, University of Zurich, Zurich, 8057 Switzerland

${ }^{c}$ Zelinsky Institute of Organic Chemistry; Russian Academy of Sciences, Moscow, 119991, Russian Federation

${ }^{d}$ School of Pharmacy, Faculty of Health Sciences, University of Eastern Finland, 70211 Kuopio, Finland

${ }^{e}$ Veterinary Clinical Sciences, Royal Veterinary College, Hatfield, AL9 7TA, United Kingdom

\section{ARTICLE INFO}

Article history:

Received

Revised

Accepted

Available online

Keywords:

FIV

HIV

Tetrathiocenes

Nucleocapsid

Zinc finger

\section{ABSTRACT}

A novel series of fused tetrathiocines were prepared for evaluation of activity against the nucelocapsid protein of the Feline Immunodeficiency Virus (FIV) in an in-vitro cell culture approach. The results demonstrated that the compounds display potent nanomolar activity and low toxicity against this key model of HIV infection.

2009 Elsevier Ltd. All rights reserved.
It is estimated that around 2.3 million new HIV infections occur worldwide every year and there are now about 35 million people currently living with the disease. ${ }^{1}$ This is an increase from previous years, which stems from the success in the widening of access to anti-retroviral drugs which has led to a higher prevalence as infection rates rise whilst mortality has decreased. Despite this success, current combination therapies still do not treat latent viral reservoirs within cells, ${ }^{2}$ requiring dosing regimens which ultimately lead to resistant HIV strains, necessitating the constant development of new innovative drugs to combat resistance. ${ }^{3}$

There are many 'druggable' targets in the HIV life cycle, which have led to a number of drug classes such as fusion/CCR5, reverse transcription, intergrase and protease inhibitors amongst others. However, whilst these can provide effective control of the virus, they do not lead to eradication of HIV from the infected patient. ${ }^{4}$ One potential target for this, is the mutation resistant nucleocapsid protein which plays a crucial role throughout the viral life cycle by promoting strand annealing by $\mathrm{RNA}_{3}{ }^{\text {Lys }}$ to the primer binding site, ${ }^{5-7}$ the integration of viral DNA into the host chromosome $^{8-9}$ and in the dimerisation and packaging of full- length viral RNA into new virions and as such, represents an attractive proposition for the development of new drug classes. ${ }^{8-9}$<smiles>CCOC(=O)c1nnsc1Nc1ccccc1Nc1snnc1C(=O)OCC</smiles><smiles>COc1cccc(/C=C2\SC(=S)C(N)C2=O)c1OC</smiles>
CMPD-1 - 2<smiles>NS(=O)(=O)c1ccc(NC(=O)c2ccccc2SSc2ccccc2C(=O)Nc2ccc(S(N)(=O)=O)cc2)cc1</smiles><smiles>NC(=O)CCNC(=O)c1ccccc1SC(=O)c1cccnc1</smiles>

DIBA-1 - 3<smiles>CCC(CSCC(=O)Br)C(C(=O)O)n1sc2ccccc2c1=O</smiles><smiles>NC(=O)NN=C(N)OCCOCCO</smiles>

PATES - 4<smiles>O=S1(=O)CC(O)C(O)CS1</smiles>

Dithiane - 7

Figure 1. Previously reported NCp7 small molecule $\mathrm{Zn}^{2+}$ abstractors. 
Surprisingly, this biological target is not species-dependent and amongst non-human vertebrates, feline immunodeficiency virus (FIV) infection in cats is perhaps the closest biological model of HIV infection in humans, with an analogous AIDS-like disease progression. ${ }^{10}$ The prevalence of FIV is around $11 \%$ worldwide, although there are significant regional variations and there is no known cure. ${ }^{11}$ FIV and HIV are closely related to other lentiviruses including the $\operatorname{simian}^{12}$ (SIV) and equine ${ }^{13}$ (EIAV) variants, each of which is a species-specific virus using analogous protein in the viral life cycle. ${ }^{14}$ Previous compounds that were shown to act against the nucleocapsid protein of HIV-1 (NCp7) (Fig. 1) have shown encouraging results but so far have failed to make the progression to late stage clinical trials. ${ }^{15-20}$

As a result of the similarity and sequence overlap between the nucleocapsid protein of HIV and FIV, we recently initiated a research program to develop compounds that could target this key protein. We previously described the results of our first class of compounds against this key target with a series of bis [1,2]dithiolo[1,4]thiazines and bis[1,2]dithiolopyrroles that showed promising activity against FIV, but were limited by their chemical tractability. ${ }^{21}$ Mutagenesis studies have shown that this target is intolerant of mutation and transcription errors, via deletion or modification of either of the two zinc fingers and leads to virus inactivation. ${ }^{22}$ Our longer-term objective is therefore the development of a highly active, non-toxic drug candidate against the nucleocapsid protein, which would represent a major breakthrough in the treatment of HIV in humans and FIV in cats.

The nucleocapsid protein is a short nucleic acid binding protein which contains two key zinc fingers, with each derived from one histidine and three cysteine residues, tetrahedrally coordinated to $\mathrm{Zn}^{2+22-24}$ This motif is conserved among nearly all known lentiviruses and various electrophilic agents have been investigated for their effects to cause HIV-1 inhibition, by covalent modification of the nucleophilic zinc finger cysteine thiolates leading to zinc ejection from either zinc finger as shown below (Fig. 2). ${ }^{25}$

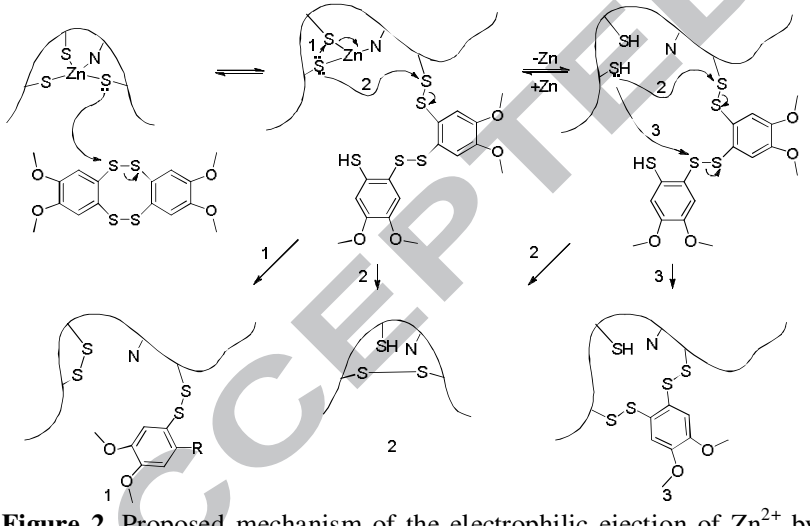

Figure 2. Proposed mechanism of the electrophilic ejection of $\mathrm{Zn}^{2+}$ by fused 1,2,5,6-tetrathiocine 9 .

The electrophilic nature of a number of previously reported compounds (Fig. 1), corresponds to their activity against the nucleocapsid protein and successful $\mathrm{Zn}^{2+}$ ejection. The next phase of our research program therefore focused on the design of compounds that could exploit this characteristic (Fig. 3). ${ }^{26-29}$ Fused 1,2,5,6-tetrathiocines are ideal in this sense as they contain two disulfide motifs in an eight-membered heterocyclic ring formation, with the result that both are in close proximity to each other. Tetrathiocines conjugated with aromatic rings have shown high anti-microbial activity toward Candida albicans ${ }^{30}$ and antifungicidal activity toward Staphylococcus aureus, Escherichia coli, and Saccharomyces cerevisiae. ${ }^{31}$
The likely mechanism of action for $\mathrm{Zn}^{2+}$ ejection is nucleophilic attack on the $\mathrm{Zn}-\mathrm{S}$ bond by compound $\mathbf{9}$, with a form of redox reaction between the cysteine thiolates followed by successful chelation and subsequent ejection (Figs. 2 and 3). There is a requirement for a second functionality in this proposed mechanism, which prompted us to look into self-contained compounds that contain two disulfide functional groups. This could potentially lead to a decrease in dose and a corresponding increase in potency. However synthetic methods have generally been limited to the oxidation of poorly available starting compounds such as vicinal 1,2-dithioles and their deriyatives ${ }^{32-35}$ or desulfurisation of benzo-1,2,3-trithioles. ${ }^{36-37}$

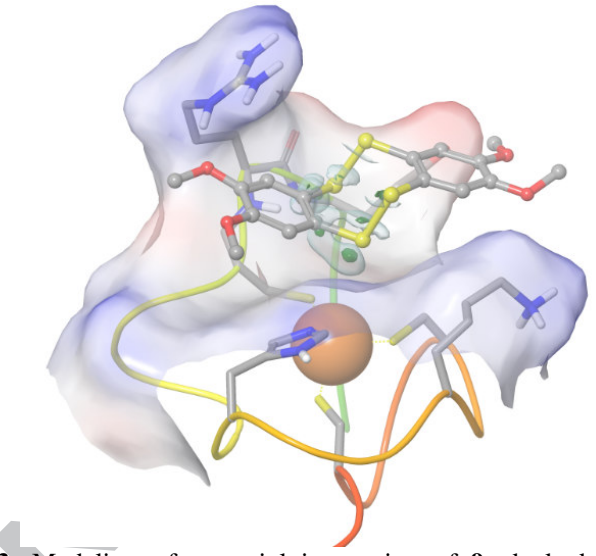

Figure 3. Modeling of potential interaction of 9, docked using QMpolarized ligand docking and Fukui+ function in the Schrödinger Suite 2013, locally visualized to proposed reactive sulfur (gray colour used for isovalue 0.001 and green for 0.005 green) with the $\mathrm{NCp} 7$ of HIV as a model for the FIV NCp.

The synthetic strategy we employed for their syntheses, involved reaction of sulfur monochloride with activated aromatic derivatives and nucleophilic heterocycles as shown in Scheme 1. Sulfur monochloride was employed in our synthetic strategy as it could be used in a one pot protocol either alone or activated with 1,4-diazobicyclo[2.2.2] octane (DABCO). ${ }^{38,39}$ Our approach enabled us to rapidly produce a number of various fused 1,2,5,6tetrathiocine analogues in high yields and under mild conditions.

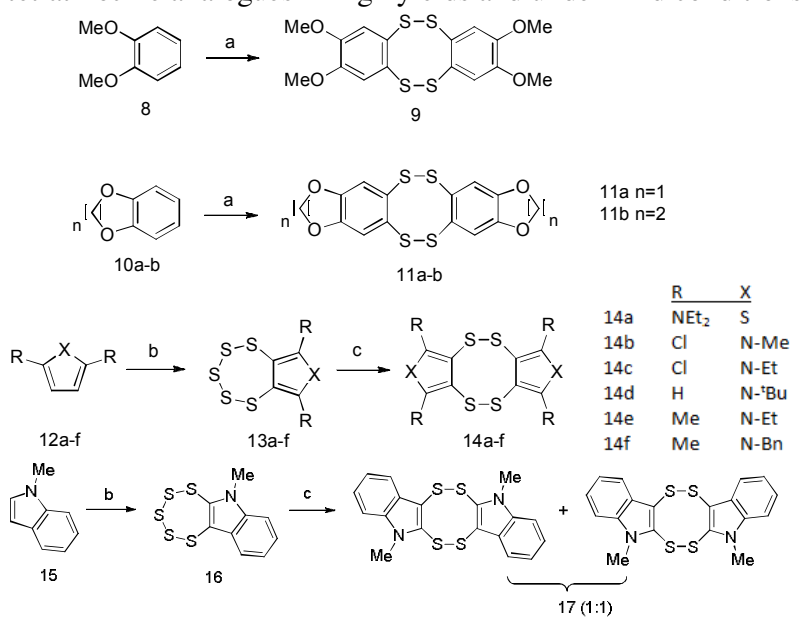

Scheme 1. Reagents and conditions - (a) acetic acid, $\mathrm{S}_{2} \mathrm{Cl}_{2}, 48 \mathrm{hr}$, rt, then $\mathrm{SnCl}_{2} / \mathrm{MeOH}$; (b) $\mathrm{S}_{2} \mathrm{Cl}_{2}, \mathrm{DABCO}, \mathrm{CHCl}_{3},-35{ }^{\circ} \mathrm{C}$, then $48 \mathrm{hr}$, rt and $\mathrm{Et}_{3} \mathrm{~N}, 3 \mathrm{hr}$, reflux; (c) $\mathrm{NaCN}, \mathrm{MeCN}, 1 \mathrm{hr}$.

Fused 1,2,5,6-tetrathiocines were prepared by treatment of sulfur monochloride with ortho-disubstituted aromatic substrates $(\mathbf{8}, \mathbf{1 0 a}-\mathbf{b})$ in acetic acid, followed by trituration with methanolic tin(II)chloride, producing the corresponding 1,2,5,6tetrathiocines $(\mathbf{9}, \mathbf{1 1 a}-\mathbf{b})$ in yields similar to that previously reported. ${ }^{40,41}$ The DABCO activated approach used a two-step procedure, involving production of 1,2,3,4,5-pentathiepins, 
which underwent reduction to form fused 1,2,5,6tetrathiocines. ${ }^{42,43}$ This was achieved by dropwise addition of sulfur monochloride to a solution of DABCO in chloroform at $35^{\circ} \mathrm{C}$ to form a $1: 2$ complex after 1 hour, which was followed by the addition of various heterocycles 12a-f and the reaction allowed to stir at room temperature for 48 hours yielding the corresponding pentathiepino-fused heterocycles 13a-f. ${ }^{44-46}$ 13a-f were suspended in acetonitrile and treated with sodium cyanide for 1 hour after which the fused 1,2,5,6-tetrathiocines (14a-f) formed in good yield (54-74\%). ${ }^{47,48}$ When the same method was applied with compound $\mathbf{1 5}$ to form the asymmetric indolopentathiepine $\mathbf{1 6}$ two regioisomers - $\mathbf{1 7}$, were formed as a 1:1 inseparable mixture as shown (Sch. 1). ${ }^{47}$

With obtention of the planned chemical targets, the biological testing was split into two stages, with the first looking at toxicity over two stages, where the first ruled out high cytotoxic compounds with a short assay over 24 hours, exposing Crandell Rees Feline Kidney cells (CrFK) to three higher concentrations $(100 \mu \mathrm{M}-1 \mu \mathrm{M})$ of the test compounds. The second stage gave an enhanced longer-term cytotoxicity screen and an anti-FIV profile that was realised over seven days at six concentrations ranging between $100 \mu \mathrm{M}$ and $1 \mathrm{nM}$, using an IL-2 independent feline lymphoblastoid cell line (FL-4).

The 24-hour assay on CRFK cells ruled out any major toxicity issues, as cytotoxic compounds removed at an early stage can prevent later false positives, with an MTT assay used to quantify the level of cell viability. ${ }^{49}$ Compounds that passed the initial 24-hour exposure test with viability above $75 \%$ at $10 \mu \mathrm{M}$ on $\mathrm{CrFK}$ cells were then screened against FIV.

FL-4 cells infected with FIV were exposed to the compounds over a period of seven days and sampled every day and at each of six concentrations. To determine the extent of viral replication, viral RNA was isolated from cell culture supernatants in a MagNA Pure LC System using the Total Nucleic Acid Isolation Kit (Roche Applied Science) and were subsequently used to determine the viral load by a quantitative real-time reversetranscription polymerase chain reaction (RT-qPCR) for FIV RNA. $^{50}$ The screening results were also checked for their viability using the MTT assay to rule out any toxicity effects validating the RT-qPCR result.

Table 1. Results of cytotoxic screening and FIV viral loading of the fused-tetrathiocine derivatives.

\begin{tabular}{cccccc}
\hline Compound & $\mathrm{CrFK}^{\mathrm{a}}$ & $\mathrm{CC}^{\mathrm{b}} \mathrm{b}^{\mathrm{n}}$ & $\mathrm{EC}^{\mathrm{b}}$ & $\mathrm{TI}^{\mathrm{c}}$ & $\operatorname{clog}^{\mathrm{d}}$ \\
\hline Number & Viability & $\mu \mathrm{M}$ & $\mu \mathrm{M}$ & & \\
\hline $\mathbf{9}$ & 75.35 & $>100$ & 0.0309 & $>3236$ & 4.14 \\
$\mathbf{1 1 a}$ & 77.01 & 5.79 & 0.0932 & 62.1 & 4.75 \\
$\mathbf{1 1 b}$ & 91.07 & $>100$ & 0.0689 & $>1451$ & 4.67 \\
$\mathbf{1 3 a}$ & $>100$ & 4.23 & 0.1687 & 25.1 & 5.89 \\
14a & $>100$ & $>100$ & $>100$ & 1 & 9.43 \\
$\mathbf{1 4 b}$ & $>100$ & $>100$ & 0.2045 & $>489$ & 5.96 \\
$\mathbf{1 4 c}$ & $>100$ & $>100$ & $>100$ & 1 & 7.01 \\
$\mathbf{1 4 d}$ & $>100$ & $>100$ & 14.500 & $>6.9$ & 8.43 \\
14e & $>100$ & $>100$ & 60.660 & 1.6 & 6.74 \\
14f & $>100$ & 58.22 & 3.0800 & 18.9 & 8.62 \\
$\mathbf{1 7}$ & $>100$ & $>100$ & 0.0429 & $>2331$ & 5.85 \\
AZT & $>100$ & $>100$ & 5.3100 & $>18.8$ & -0.16 \\
Raltegravir & $>100$ & $>100$ & 0.0100 & $>10000$ & 1.16
\end{tabular}

${ }^{a}$ Sample concentration of $10 \mu \mathrm{M}$ of compound on CrFK cells for 24 hours percentage viability; ${ }^{\mathrm{b}} \mathrm{Geometric}$ mean, each concentration tested in triplicate after 7 days as a difference of the untreated FL-4 cells; ${ }^{\circ}$ Therapeutic index is $\mathrm{CC}_{50} / \mathrm{EC}_{50}$, which is the ratio of toxicity to activity; ${ }^{\mathrm{d}}$ Calculated using ChemBioDraw Ultra 12.
The results obtained, indicated that the para-disubstituted fused 1,2,5,6-tetrathiocines (9, 11a-b \& 17) gave generally favorable toxicity profiles and good activity, with most CC50s above $100 \mu \mathrm{M}$ and activities in the low nanomolar range (Tab. 1). 1,2,5,6-Tetrathiocines with fused heterocyclic rings (14a-f) were not as effective possibly due to the higher $\operatorname{cLogP}$ considering the ratio of activity to toxicity. Once the cLogP increases above six, activity decreases and is much closer to the toxicity profile of the compound, which is perhaps to be expected as solubility of the compounds reduces in the assay medium. It is interesting to note that testing of intermediate 13a gave reasonable results with a therapeutic index of 25 , which could be used as a potential lead compound in a new series. The activity of AZT and Raltegravir are consistent with previous reports in FIV/HIV. ${ }^{51,52}$

Overall, these results indicate that the nucleocapsid protein of FIV can be targeted effectively with symmetrical dual functionality compounds with high efficacy. The relative simplicity and tractability of the synthetic approach makes these compounds attractive for further development and optimization. The high therapeutic index and potency of 9 indicates that there is potential for further development of this series of compounds to improve the toxicity profiles and bioavailability. The results of our investigations into this will be reported in due course.

\section{Acknowledgments}

The authors are grateful to Bloomsbury Colleges - University of London; Pet Plan Charitable Trust; University College London; University of Zurich \& Biocenter Finland/DDCB for financial support towards the goals of our work. Thanks also go to the University of Zurich and the Center for Clinical Studies at the Vetsuisse Faculty for the use of their facilities, the CSC-IT Center for Science Ltd. - Finland, for the allocation of computational resources. We also thank the EPSRC UK National Mass Spectrometry Facility at Swansea University for spectroscopic services.

\section{References and notes}

1. UNAIDS 2013, AIDS Epidemic Update.

2. Coiras, M.; López-Huertas, M. R.; Pérez-Olmeda, M.; Alcamí, J. Nat. Rev. Microbiol. 2009, 11, 798.

3. Iversen, A. K.; Shafer, R. W.; Wehrly, K.; Winters, M. A.; Mullins, J. I.; Chesebro, B.; Merigan, T. C. J. Virol. 1996, 70, 1086.

4. Miller, V.; Larder, B. A. Antivir. Ther. 2001, 6, 25.

5. Tanchou, V.; Decimo, D.; Péchoux, C.; Lener, D.; Rogemond, V.; Berthoux, L.; Ottmann, M.; Darlix J-L. J. Virol. 1998, 72, 4442.

6. Remy, E.; de Rocquigny H.; Petitjean, P.; Muriaux, D.; Theilleux, V.; Paoletti, J.; Roques, B. P. J. Biol. Chem. 1998, 273, 4819.

7. Rong, L.; Liang, C.; Hsu, M.; Kleiman, L.; Petitjean, P.; de Rocquigny, H.; Roques, B. P.; Wainberg, M. A. J. Virol. 1998, 72, 9353.

8. Gao, K.; Gorelick, R. J.; Johnson, D. G.; Bushman, F. J. Virol. 2003, 77, 1598.

9. Carteau, S.; Batson, S. C.; Poljak, L.; Mouscadet, J. F.; de Rocquigny, H.; Darlix, J. L.; Roques, B. P.; Käs, E.; Auclair, C. J. Virol. 1997, 71, 6225 .

10. Elder, J. H.; Lin, Y-C.; Fink, E.; Grant, C. K. Current HIV Research, 2010, 8,73 .

11. Richards, J. R. Biologicals 2005, 33, 215.

12. Letvin, N. L.; Eaton, K. A.; Aldrich, W. R.; Sehgal, P. K.; Blake, B. J.; Schlossman, S. F.; King, N. W.; Hunt, R. D. Proc. Natl. Acad. Sci. 1983, $80,2718$.

13. Vallee, H.; Carré, H. C. R. Hebd. Acad. Sci. 1904, 139, 331.

14. Goldschmidt, V.; Jenkins, L. M.; de Rocquigny, H.; Darlix, J-L.; Mély, Y. HIV Therapy, 2010, 4, 179.

15. Pannecouque, C.; Szafarowicz, B.; Volkova, N.; Bakulev, V.; Dehaen, W.; Mély, Y.; Daelemans, D. Antimicrob. Agents Chemother. 2010, 54, 1461.

16. Maynard, A. T.; Huang, M.; Rice, W. G.; Covell, D. G. Proc. Natl. Acad. Sci. 1998, 95, 11578 . 
17. Breuer, S.; Chang, M. W.; Yuan, J.; Torbett, B. E. J. Med. Chem. 2012, $55,4968$.

18. Mayasundari, A.; Rice, W. G.; Diminnie, J. B.; Baker, D. C. Bioorg. Med. Chem. 2003, 11, 3215.

19. Turpin, J. A.; Song, Y.; Inman, J. K.; Huang, M.; Wallqvist, A.; Maynard, A.; Covell, D. G.; Rice, W. G.; Appella, E. J. Med. Chem. 1999, 42, 67.

20. Rice, W.G., Turpin, J. A.; Huang, M.; Clanton, D.; Buckheit, R. W. Jr.; Covell, D. G.; Wallqvist, A.; McDonnell, N. B.; DeGuzman, R. N.; Summers, M. F.; Zalkow, L.; Bader, J. P.; Haugwitz, R. D.; Sausville, E. A. Nat. Med. 1997 3, 341.

21. Asquith, C. R. M.; Meli, M. L.; Konstantinova, L. S. Laitinen, T.; Peräkylä, M.; Poso, A.; Rakitin, O. A.; Allenspach, K.; HofmannLehmann, R.; Hilton, S. T. Bioorg. Med. Chem. Lett. 2014, 24, 2640.

22. Schmalzbauer, E.; Strack, B.; Dannull, J.; Guehmann, S.; Moelling, K. J Virol._1996, 70, 771.

23. Ramboarina, S.; Druillennec, S.; Morellet, N.; Bouaziz, S.; Roques B. P. J.Virol. 2004, 78, 6682.

24. Darlix, J.; Lapada-Tapolsky, M.; de Rocquigny, H.; Roques, B. J. Mol. Biol. 1995, 254, 523.

25. Jenkins, L. M.; Byrd, J. C.; Hara, T.; Srivastava, P.; Mazur, S. J.; Stahl, S. J.; Inman, J. K.; Appella, E.; Omichinski, J. G.; Legault, P. J. Med. Chem. 2005, 48, 2847.

26. Schrödinger Release 2013-3: Maestro, version 9.6; Ligprep, version 2.8; Protein Preparation Wizard: Epik version 2.6, Impact version 6.1, Prime version 3.4.; QM-Polarized Ligand Docking protocol: Glide version 6.1, Jaguar version 8.2, QSite version 6.1, Schrödinger, LLC, New York, NY, 2013.

27. Loo, J. A.; Holler, T. P.; Sanchez, J.; Gogliotti, R.; Maloney, L.; Reily, M. D. J. Med. Chem. 1996, 39, 4313.

28. Manrique, M. L.; Rauddi, M. L.; González, S. A.; Affranchino, J. L. Virology. 2004, 327, 83.

29. Bourbigot, S.; Ramalanjaona, N.; Boudier, C.; Salgado, G. F.; Roques, B. P.; Mely, Y.; Bouaziz, S.; Morellet, N. J. Mol. Biol. 2008, 383, 1112.

30. Nakazawa, T.; Xu, J.; Nishikawa, T.; Oda, T.; Fujita, A.; Ukai, K.; Mangindaan, R. E. P.; Rotinsulu, H.; Kobayashi, H.; Namikoshi, M. J. Nat. Prod. 2007, 70, 439

31. Searle P. A.; Molinski, T. F. J. Org. Chem. 1994, 59, 6600.

32. Chivers, T.; Parvez, M.; Schatte, G.; Vargas-Baca, I.; Can. J. Chem. 1998, 76, 1093.

33. Cava, M. P.; Chen, W.; Rogers, R. D.; Zong, K. J. Org. Chem. 1996, 61, 8117

34. Yamamoto, T.; Ogawa, S.; Sugawara, M.; Kawai, Y.; Sato, R. Bull. Chem. Soc. Jpn. 2006, 79, 460 .

35. Aragoni, M. C.; Arca, M.; Devillanova, F. A.; Isaia, F.; Lippolis, V.; Mancini, A.; Pala, L.; Slawin, A. M. Z.; Woollins, J. D. Chem. Commun. 2003, 2226

36. Kimura, T.; Mizusawa, S.; Yoneshima, A.; Ito, S.; Tsujimura, K.; Yamashita, T.; Kawai, Y.; Ogawa, S.; Sato, R. Bull. Chem. Soc. Jpn. 2002, 75, 2647.

37. Kimura, T.; Tsujimura, K.; Mizusawa, S.; Ito, S.; Kawai, Y.; Ogawa, S.; Sato, R. Tetrahedron Lett. 2000, 41, 1801.

38. Rakitin, O. A.; Konstantinova, L. S. Adv. Heterocycl. Chem. 2008, 96, 175 .

39. Konstantinova, L. S.; Rakitin, O. A. Russ. Chem. Rev. 2014, 83, 225.

40. Alberola, A.; Eisler, D.; Less, R. J.; Navarro-Moratalla, E.; Rawson, J. M. Chem. Commun. 2010, 46, 6114.

41 Stender, K-W.; Woelki, N.; Klar, G. Phosphorus, Sulfur Silicon Relat. Elem. 1989, 42, 111.

42. Konstantinova, L. S.; Rakitin, O. A.; Rees, C. W. Chem. Rev., 2004, 104, 2617.

43. Konstantinova, L. S.; Rakitin, O. A.; Amelichev, S. A. Russ. Chem. Rev. 2007, 76, 195.

44. Konstantinova, L. S.; Rakitin, O. A.; Souvorova, L. I.; Rees, C. W.; Golovanov, D. G.; Lyssenko, K. A. Org. Lett. 2003, 5, 1939.

45. Amelichev, S. A.; Konstantinova, L. S.; Rakitin, O. A.; Lyssenko, K. A.; Rees, C. W. Org. Biomol. Chem. 2005, 3, 3496.

46. Amelichev, S. A.; Aysin, R. R.; Konstantinova, L. S.; Obruchnikova, N. V.; Rakitin, O. A.; Rees, C. W. Org. Lett. 2005, 7, 5725.

47. Konstantinova, L. S.; Amelichev, S. A.; Rakitin, O. A. Russ. Chem. Bull. 2007, 56, 1540.

48. Synthesis of tetrathiocines (general procedure). Sodium cyanide $(0.15$ $\mathrm{g}, 3 \mathrm{mmol}$ ) was added over 20 minutes to a vigorously stirred solution of pentathiepine $(1 \mathrm{mmol})$ in acetonitrile $(400 \mathrm{~mL})$ at room temperature. The reaction mixture was stirred for a further 1 hour at room temperature and solvent removed under reduced pressure. The solid residue was washed with dichloromethane $(3 \times 100 \mathrm{~mL})$. The combined extracts were washed with water $(3 \times 100 \mathrm{~mL})$, dried $\left(\mathrm{MgSO}_{4}\right)$ and solvent removed under reduced pressure, and the resulting solid residue dried in vacuo (at 5 Torr).

$N, N, N^{\prime}, N^{\prime}, N^{\prime \prime}, N^{\prime \prime}, N^{\prime \prime \prime}, N^{\prime \prime \prime}-$ Octaethylbisthieno[3,4-c:3',4'-

g] $[1,2,5,6]$ tetrathiocine-1,3,6,8-tetramine, (14a): Yellow crystals $(64 \%$, $0.37 \mathrm{~g}$ ); mp 157-159 ${ }^{\circ} \mathrm{C}$; Anal. Calcd for $\mathrm{C}_{24} \mathrm{H}_{40} \mathrm{~N}_{4} \mathrm{~S}_{6}$ : C, 49.96; H, 6.99; N, 9.71. Found: C, 50.25; H, 7.18; N, 9.62; ${ }^{1} \mathrm{H}$ NMR (Pyr- $\left.d_{5} 500 \mathrm{MHz}\right)$, $\delta: 1.22\left(\mathrm{t}, 24 \mathrm{H}, \mathrm{CH}_{3}, J=7.0 \mathrm{~Hz}\right), 3.20\left(\mathrm{q}, 16 \mathrm{H}, \mathrm{CH}_{2}, J=7.0 \mathrm{~Hz}\right) ;{ }^{13} \mathrm{C}$ NMR (Pyr- $\left.d_{5} 100 \mathrm{MHz}\right), \delta: 13.4\left(\mathrm{CH}_{3}\right), 50.8\left(\mathrm{CH}_{2}\right), 122.6(\mathrm{C}), 153.9(\mathrm{C})$; MS (EI, $70 \mathrm{eV}), \mathrm{m} / \mathrm{z}(\%): 576\left([\mathrm{M}]^{+}, 12\right), 512(20), 288(45), 259(100)$, 244 (40). HMRS: found $\mathrm{m} / z$ 577.1665; calc. for $\mathrm{C}_{24} \mathrm{H}_{40} \mathrm{~N}_{4} \mathrm{~S}_{6}[\mathrm{M}+\mathrm{H}]+$ 577.1655 .

1,3,6,8-Tetrachloro-2,7-diethyl[1,2,5,6]tetrathiocino[3,4-c:7,8-

c']dipyrrole, (14c): Yellow crystals $\left(70 \%, 0.32\right.$ g); m.p. $310-312{ }^{\circ} \mathrm{C}$; Anal. Calcd. for $\mathrm{C}_{12} \mathrm{H}_{10} \mathrm{C}_{14} \mathrm{~N}_{2} \mathrm{~S}_{4}$ : C, 31.87; H, 2.23; N, 6.19. Found: C, 31.72; H, 2.04; N, 6.32.; ${ }^{1} \mathrm{H}$ NMR $\left(\mathrm{Pyr}-d_{5} 500 \mathrm{MHz}\right) \delta: 1.01(\mathrm{t}, 6 \mathrm{H}, J=$ $\left.7.3 \mathrm{~Hz}, \mathrm{CH}_{3}\right), 3.73$ (q, $\left.4 \mathrm{H}, J=7.3 \mathrm{~Hz}, \mathrm{CH}_{2}\right) ;{ }^{13} \mathrm{C}$ NMR (Pyr- $\left.d_{5} 100 \mathrm{MHz}\right)$

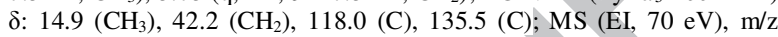
(\%): $450\left([\mathrm{M}]^{+}, 20\right), 392$ (2), 390 (20), 388 (42), 386 (28), 29 (100); HMRS: found $m / z$ : $450.8554 ;[\mathrm{M}+\mathrm{H}]^{+}$calc. for $\mathrm{C}_{12} \mathrm{H}_{11} \mathrm{C}_{14} \mathrm{~N}_{2} \mathrm{~S}_{4} 450.8554$. 2,7-Bis(tert-butyl) $[1,2,5,6]$ tetrathiocino[3,4-c:7,8-c $]$ dipyrrole (14d): Yellow crystals $\left(74 \%, 0.27\right.$ g); m.p. 190-192 ${ }^{\circ} \mathrm{C}$; Anal. Calcd. For $\mathrm{C}_{16} \mathrm{H}_{22} \mathrm{~N}_{2} \mathrm{~S}_{4}$ : C, 51.85; H, 5.98; N, 7.56; Found: C, 51.98; H, 6.20; N, $7.90 ;{ }^{1} \mathrm{H} \mathrm{NMR}\left(\mathrm{CDCl}_{3} 500 \mathrm{~Hz}\right) \delta: 1.51\left(\mathrm{~s}, 18 \mathrm{H}, \mathrm{CH}_{3}\right), 7.06(\mathrm{~s}, 4 \mathrm{H}, \mathrm{CH})$; ${ }^{13} \mathrm{C} \mathrm{NMR}\left(\mathrm{CDCl}_{3} 100 \mathrm{MHz}\right) \delta: 30.27\left(\mathrm{CH}_{3}\right), 125.38(\mathrm{CH}), 56.16(\mathrm{C})$, 119.43 (C); MS (EI, $70 \mathrm{eV}), \mathrm{m} / \mathrm{z}(\%): 370\left(\mathrm{M}^{+}, 90\right), 306(90), 250$ (65), 194 (100), 64 (90); HMRS: found $\mathrm{m} / z:$ 370.0654: $[\mathrm{M}]^{+}$calc. for $\mathrm{C}_{16} \mathrm{H}_{22} \mathrm{~N}_{2} \mathrm{~S}_{4} 370.0666$.

1,3,6,8-Tetramethyl-2,7-diethyl[1,2,5,6]tetrathiocino[3,4-c:7,8-

c']dipyrrole, (14e): Yellow crystals (73\%, 0.27 g); m.p. 293-295 ${ }^{\circ} \mathrm{C}$; Anal. Calcd. for $\mathrm{C}_{16} \mathrm{H}_{22} \mathrm{~N}_{2} \mathrm{~S}_{4}$ : C, 51.85; H, 5.98; N, 7.56.; Found: C, $51.72 ; \mathrm{H}, 5.81 ; \mathrm{N}, 7.82 ;{ }^{1} \mathrm{H}$ NMR $\left(\mathrm{Pyr}-d_{5} 500 \mathrm{MHz}\right) \delta: 0.94(\mathrm{t}, 6 \mathrm{H}, J=$ $\left.7.3 \mathrm{~Hz}, \mathrm{CH}_{3}\right), 2.29\left(\mathrm{~s}, 6 \mathrm{H}, \mathrm{CH}_{3}\right), 2.35\left(\mathrm{~s}, 3 \mathrm{H}, \mathrm{CH}_{3}\right), 2.41\left(\mathrm{~s}, 3 \mathrm{H}, \mathrm{CH}_{3}\right)$, $3.53\left(\mathrm{q}, 4 \mathrm{H}, J=7.3 \mathrm{~Hz}, \mathrm{CH}_{2}\right), 0.94\left(\mathrm{t}, 6 \mathrm{H}, J=7.3 \mathrm{~Hz}, \mathrm{CH}_{3}\right), 2.29(\mathrm{~s}, 6 \mathrm{H}$, $\mathrm{CH}_{3}$ ), 2.35 (s, 3H, Me), 2.41 (s, 3H, Me), 3.53 (q, 4H, $J=7.3 \mathrm{~Hz}, \mathrm{CH}_{2}$ ); ${ }^{13} \mathrm{C}$ NMR (Pyr-d $\left.100 \mathrm{MHz}\right), \delta: 11.0\left(\mathrm{CH}_{3}\right) ; 15.7\left(\mathrm{CH}_{3}\right) ; 40.1\left(\mathrm{CH}_{2}\right)$; 117.2, 134.6 (two quaternary $\mathrm{C}$ atoms); $\mathrm{MS}$ (EI, $70 \mathrm{eV}), \mathrm{m} / \mathrm{z}(\%): 370$ $\left([\mathrm{M}]^{+}, 23\right), 338$ (37), 306 (58), 273 (29), 217 (28), 184 (45), 152 (52), 42 (100); HMRS: found $m / z$ 371.0737: $[\mathrm{M}+\mathrm{H}]^{+}$calc. for $\mathrm{C}_{16} \mathrm{H}_{23} \mathrm{~N}_{2} \mathrm{~S}_{4}$ 371.0744

1,3,6,8-Tetramethyl-2,7-dibenzyl[1,2,5,6]tetrathiocino[3,4-c:7,8-

c']dipyrrole, (14f): Yellow crystals $\left(71 \%, 0.35\right.$ g); m.p. $305-307{ }^{\circ} \mathrm{C}$; Anal. Calcd. for $\mathrm{C}_{26} \mathrm{H}_{26} \mathrm{~N}_{2} \mathrm{~S}_{4}$ : C, 63.12; H, 5.30; N, 5.66. Found: C, 63.33; $\mathrm{H}, 5.42 ; \mathrm{N}, 5.31$; $1 \mathrm{H} \mathrm{NMR}\left(\mathrm{Pyr}-d_{5} 500 \mathrm{MHz}\right) \delta: 2.29\left(\mathrm{~s}, 12 \mathrm{H}, \mathrm{CH}_{3}\right) ; 4.95$ $\left(\mathrm{s}, 4 \mathrm{H}, \mathrm{CH}_{2}\right), 6.95(\mathrm{~d}, 4 \mathrm{H}, J=7.3 \mathrm{~Hz}, \mathrm{CH}), 7.24-7.29(\mathrm{~m}, 6 \mathrm{H}, \mathrm{CH}) ;{ }^{13} \mathrm{C}$ NMR (Pyr- $\left.d_{5} 100 \mathrm{MHz}\right) \delta$ : $11.40\left(\mathrm{CH}_{3}\right), 48.62\left(\mathrm{CH}_{2}\right), 117.25(\mathrm{C}$ atom), $126.5(\mathrm{CH}), 128.1(\mathrm{CH}), 129.6(\mathrm{CH}), 135.8(\mathrm{CH}), 137.8(\mathrm{C})$; MS (EI, 70 $\mathrm{eV}), \mathrm{m} / \mathrm{z}(\%): 494\left([\mathrm{M}]^{+}, 8\right), 430$ (18), 339 (15), 248 (23), 91 (100); HMRS: found $m / z$ 495.1061: $[\mathrm{M}+\mathrm{H}]^{+}$calc. for $\mathrm{C}_{26} \mathrm{H}_{27} \mathrm{~N}_{2} \mathrm{~S}_{4} 495.1057$.

49. Sylvester, P. W. Methods Mol. Biol. 2011, 716, 157.

50. Klein, D.; Leutenegger, C. M.; Bahula, C.; Gold, P.; Hofmann-Lehmann, R.; Salmons, B.; Lutz, H.; Gunzburg, W. H. J Acquir Immune Defic Syndr. 2001 26, 8 .

51. Bisset, L. R.; Lutz, H.; Böni, J.; Hofmann-Lehmann, R.; Lüthy, R.; Schüpbach, J. Antiviral. Res. 2002, 53, 35.

52. Hazuda, D. J.; Anthony, N. J.; Gomez, R. P.; Jolly, S. M.; Wai, J. S.; Zhuang, L.; Fisher, T. E.; Embrey, M.; Guare, J. P. Jr.; Egbertson, M. S.; Vacca, J. P.; Huff, J. R.; Felock, P. J.; Witmer, M. V.; Stillmock, K. A.; Danovich R, Grobler, J.; Miller, M. D.; Espeseth, A. S.; Jin, L.; Chen, I. W.; Lin, J. H.; Kassahun, K.; Ellis, J. D.; Wong, B. K.; Xu, W.; Pearson, P. G.; Schleif, W. A.; Cortese, R.; Emini, E.; Summa, V.; Holloway, M. K.; Young, S. D. Proc. Natl. Acad. Sci. U.S.A. 2004, 101, 11233. 